\title{
Life cycle energy and environmental analysis of a microgrid power pavilion
}

\author{
David V. Spitzley ${ }^{1}$, Gregory A. Keoleian ${ }^{1, *, \dagger}$ and Scott G. Baron ${ }^{2}$ \\ ${ }^{1}$ Center for Sustainable Systems, University of Michigan, 3504 Dana, 440 Church Street, Ann Arbor, \\ MI 48109-1041, U.S.A \\ ${ }^{2}$ GE Energy, 1 River Rd., Building 37-363, Schenectady, NY 12345, U.S.A.
}

\begin{abstract}
SUMMARY
Microgrids-generating systems incorporating multiple distributed generator sets linked together to provide local electricity and heat-are one possible alterative to the existing centralized energy system. Potential advantages of microgrids include flexibility in fuel supply options, the ability to limit emissions of greenhouse gases, and energy efficiency improvements through combined heat and power (CHP) applications. As a case study in microgrid performance, this analysis uses a life cycle assessment approach to evaluate the energy and emissions performance of the NextEnergy microgrid Power Pavilion in Detroit, Michigan and a reference conventional system. The microgrid includes generator sets fueled by solar energy, hydrogen, and natural gas. Hydrogen fuel is sourced from both a natural gas steam reforming operation and as a by-product of a chlorine production operation. The chlorine plant receives electricity exclusively from a hydropower generating station. Results indicate that the use of this microgrid offers a total energy reduction potential of up to $38 \%$, while reductions in non-renewable energy use could reach $51 \%$. Similarly, emissions of $\mathrm{CO}_{2}$, a key global warming gas, can be reduced by as much as $60 \%$ relative to conventional heat and power systems. Hydrogen fuels are shown to provide a net energy and emissions benefit relative to natural gas only when sourced primarily from the chlorine plant. Copyright (C) 2006 John Wiley \& Sons, Ltd.
\end{abstract}

KEY WORDS: distributed generation; microgrid; life cycle assessment; net energy ratio

\section{INTRODUCTION}

Pressures on existing fossil fuel supplies and energy infrastructure have put renewed emphasis on alternative methods for delivering efficient, clean, and reliable power. The current

\footnotetext{
*Correspondence to: Gregory A. Keoleian, Center for Sustainable Systems, University of Michigan, 3504 Dana, 440 Church Street, Ann Arbor, MI 48109-1041, U.S.A.

†E-mail: gregak@umich.edu

Contract/grant sponsor: NextEnergy; contract/grant number: PSC-03
}

Copyright (C) 2006 John Wiley \& Sons, Ltd.

Received 30 January 2006 Revised 25 April 2006 Accepted 28 April 2006 
centralized, non-renewable fuel dominated energy infrastructure has been linked to local and regional air quality problems, global warming, depletion of limited resource stocks, and public safety risks (Tester et al., 2005). In contrast to centralized generation, distributed generation is small-scale energy conversion occurring at or close to the load being served. $\$$ Distributed generation technologies may provide electrical power only or both heat and power. These technologies may offer a more sustainable system for meeting energy needs. Advancements in distributed generation technologies, restructuring of the electric utility industry, barriers to development of new transmission lines, distribution system reliability concerns, and increasing attention focused on global climate change are driving rapid growth in implementation of distributed generation.

Microgrids are generating systems incorporating multiple distributed (grid independent or grid parallel) generator sets linked together to provide electricity and heat for a collection of local loads such as an office park, industrial complex, neighbourhood or campus. Microgrids offer the potential to utilize the best combination of power generation assets for meeting a given demand. For example, a microgrid may combine a solar photovoltaic (PV) array with a diesel generator to provide continuous power while utilizing renewable resources when available. Many of the benefits frequently associated with distributed generation also apply to microgrids, while microgrids also face many of the same challenges. Challenges that continue to provide barriers to the expansion of microgrids include the high capital costs of many technologies involved, the potential for more irregular power supply requiring various energy storage solutions, variable power quality and the necessity of power conditioning, limited fuel supply infrastructure, and the need for specially trained technicians to provide operation and maintenance (Abu-Sharkh et al., 2006). Nevertheless, the potential advantages of distributed generation relative to centralized power have continued to drive microgrid development. These advantages include the flexibility to respond to changing conditions such as peak power requirements or changes in fuel supply, avoiding grid power outages, limiting the need for additional expansion of transmission infrastructure, the opportunity to recover some generating costs by selling power on to the grid (net-metering), the ability to limit emissions of carbon dioxide $\left(\mathrm{CO}_{2}\right)$ and other greenhouse gases amid growing concerns over global climate change, and the efficiency improvement opportunities offered by combined heat and power (CHP) technologies (Pepermans et al., 2005). Strachan and Farrell found that a range of gas-fired distributed generation technologies with CHP capability offered emissions reductions relative to centralized power options. They generally attributed these reductions to the efficiency advantages offered by distributed generation when both heat and power were produced (Strachan and Farrell, 2006).

As a case study, this analysis models the expected energy and environmental performance of the NextEnergy Microgrid Power Pavilion. This generating facility is currently under development at the future NextEnergy Center in the city of Detroit, Michigan. The analysis discussed here is based on the microgrid originally envisioned for the Power Pavilion. More recently, development efforts have focused on establishment of a test-bed for short-term technology investigation rather than supporting building energy needs. Nevertheless, generator sets and fuel types modelled here are based on the microgrid designed to meet site demand and

\footnotetext{
For a detailed definition of distributed generation, readers are referred to the work of Pepermans et al. (2005) and El-Khattam and Salama (2004).
} 
Table I. Generator sets included in the NextEnergy Power Pavilion.

\begin{tabular}{|c|c|c|c|c|}
\hline Name & Fuel type & $\begin{array}{l}\text { Size } \\
(\mathrm{kW})\end{array}$ & CHP & Description \\
\hline $\mathrm{H}_{2}$ Fuel Cells & Hydrogen & 15 & & $\begin{array}{l}\text { Set of three independent } 5 \mathrm{~kW} \text { proton } \\
\text { exchange membrane fuel cells }\end{array}$ \\
\hline $\begin{array}{l}\text { NG Stirling } \\
\text { Engine }\end{array}$ & Natural gas & 104 & レ & $\begin{array}{l}\text { Two external combustion (stirling) engines, } \\
\text { induction generator set }\end{array}$ \\
\hline NG Engine-85 & Natural gas & 85 & $\nu$ & $\begin{array}{l}\text { Automotive derivative internal combustion } \\
\text { engine, synchronous generator set }\end{array}$ \\
\hline NG Engine-150 & Natural gas & 150 & V & $\begin{array}{l}\text { Automotive derivative internal combustion } \\
\text { engine, synchronous generator set }\end{array}$ \\
\hline $\mathrm{H}_{2}$ Engine & Hydrogen & 120 & & $\begin{array}{l}\text { Automotive derivative internal combustion } \\
\text { engine, synchronous generator set }\end{array}$ \\
\hline Solar Modules & Sunlight & 30 & & $\begin{array}{l}\text { Amorphous silicon thin-film photovoltaic } \\
\text { modules (approximately } 516 \mathrm{~m}^{-2} \text { ) }\end{array}$ \\
\hline
\end{tabular}

provide a useful case study in microgrid performance. For the NextEnergy site overall annual electrical demand is expected to reach $656 \mathrm{MWh}$ with 3.0 million $\mathrm{MJ}$ of heat required annually.

The Power Pavilion itself occupies approximately $520 \mathrm{~m}^{2}$ of the $4200 \mathrm{~m}^{2}$ Next Energy site (Microgrid at Michigan Power Pavilion, 2003). The mircogrid includes six generator sets, three with CHP capabilities, providing a total electrical capacity of $504 \mathrm{~kW}$. The generator sets included in the microgrid are shown in Table I. These generators are more than sufficient to meet expected building electrical and thermal loads. In the future, the Power Pavilion may be used to provide heat and electricity to a larger part of the surrounding community. This microgrid is being developed to demonstrate technology and allow for research on technology performance and design. Each generator set can be brought on- or off-line independently and the site includes conventional grid connectivity as well as conventional thermal HVAC and water systems.

\section{METHODS}

A complete understanding of the energy and environmental performance of microgrid systems requires a life cycle perspective. Life cycle assessment is an analytical technique for assessing the potential environmental burdens and impacts associated with a product system from the acquisition of the raw materials to the ultimate management of material remaining at the end of life (Keoleian and Spitzley, 2006; ISO, 1997). Life cycle assessment is applied here in the evaluation of the energy and emissions performance of the NextEnergy microgrid and a reference conventional system. Life cycle stages included in the microgrid assessment are shown in Figure 1.

\subsection{Fuel cycle analysis}

The energy and emissions associated with generator set production were generally negligible from a life cycle perspective. For example, the automotive derivative engines used in the NextEnergy Power Pavilion are similar in design, materials use and manufacturing to the automotive engines studied by Smith and Keoleian (2004). Smith and Keoleian estimate that production of a $140 \mathrm{hp}$ engine requires $11600 \mathrm{MJ}$. This value is less than $0.01 \%$ of the total 


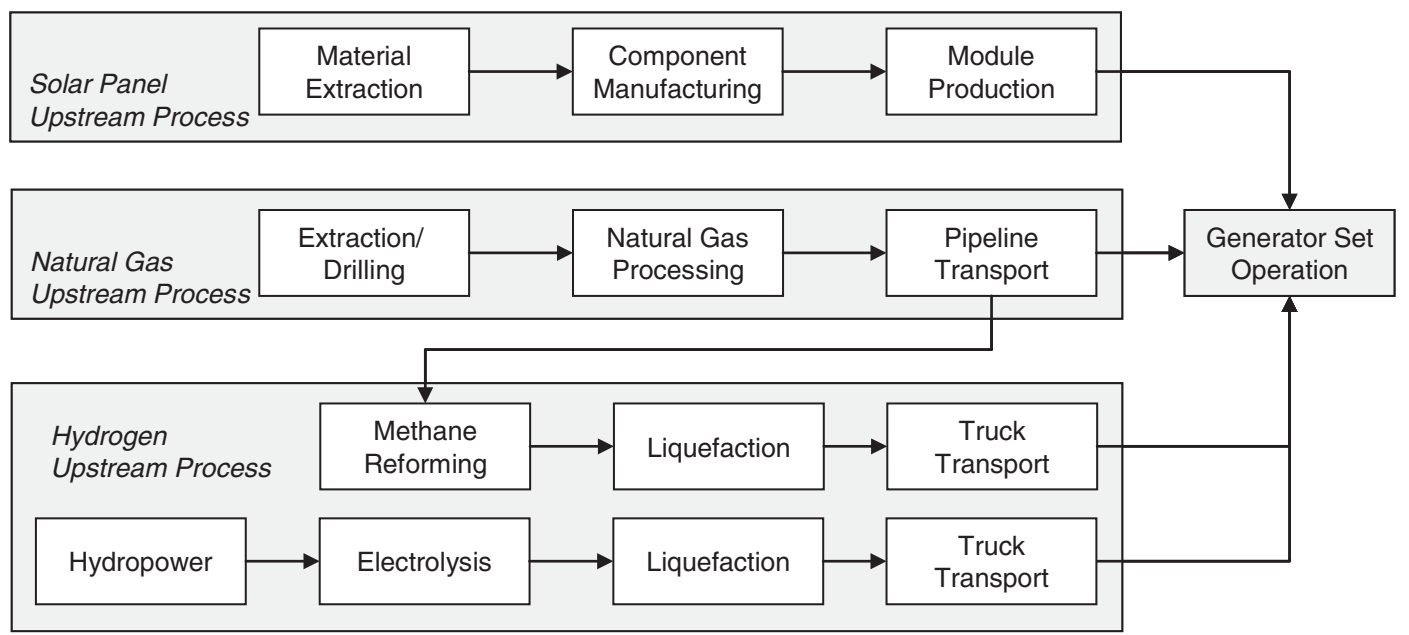

Figure 1. Life cycle stages considered in the fuel cycle assessment of a microgrid.

annual energy used in operation for the 108-225 hp engines studied here. The slight differences between the microgrid engines and those studied by Smith and Keoleian are not expected to have any dramatic effects on the relationship between production energy and operating energy. Therefore, generator set production is not included in the analysis.

The one exception to this was the solar modules. These modules do not require fuel input during use which makes the production of the generator set a more important factor in the life cycle. The energy and emissions associated with the use of the solar modules was derived from research published by Keoleian and Lewis (2003). Keoleian and Lewis found that similar amorphous silicon photovoltaic modules required $0.93 \mathrm{MJ}$ for every $\mathrm{kWh}$ of electricity produced under conditions found in Detroit for a 20 year period. A value was also determined for $\mathrm{CO}_{2}$ $\left(63.5 \mathrm{~g} \mathrm{kWh}^{-1}\right)$ following a similar procedure. These values are used as the upstream input for the solar module generator set.

All of the non-solar microgrid generator sets are fueled by either hydrogen or natural gas. The hydrogen fuel for the microgrid is produced in central plants and delivered in liquid form via tanker truck to the Power Pavilion. Hydrogen can be delivered from either of two plants in the region. One facility is located approximately $420 \mathrm{~km}$ from the microgrid and produces hydrogen in a natural gas steam reforming operation. The other potential hydrogen supply source is a chlorine production operation located $400 \mathrm{~km}$ from the Power Pavilion.

In the case of hydrogen sourced from the chlorine production (chlor-alkali) facility, hydrogen is treated as a co-product in the manufacturing process and burdens are allocated on a mass basis to three salable products: hydrogen (approximately $1.4 \%$ by mass), chlorine $(46 \%)$ and caustic soda $(52 \%)$. Although hydrogen is not necessarily a renewable fuel, the electrolysis process used to produce this fuel is fed by electricity from a nearby hydropower plant making the hydrogen fuel partially renewable. The additional liquefaction processing step is also powered by the hydroelectric plant. However, the transportation of the liquid hydrogen product to the microgrid site is accomplished through the use of tanker trucks running on fossil fuels. Ultimately the hydrogen production, processing and transportation activities require $55.1 \mathrm{MJ} \mathrm{kg}^{-1}$ of hydrogen delivered. Of this, $51.1 \mathrm{MJ} \mathrm{kg}^{-1}$ are from renewable sources. 
Table II. Fuel cycle characteristics for microgrid fuels.

\begin{tabular}{lcccc}
\hline Fuel & \multicolumn{1}{c}{ Source } & $\begin{array}{c}\text { Heating } \\
\text { value }\end{array}$ & $\begin{array}{c}\text { Upstream energy } \\
\left(\mathrm{MJ} \mathrm{MJ}^{-1} \text { delivered }\right)\end{array}$ & $\begin{array}{c}\text { Percentage } \\
\text { non-renewable }\end{array}$ \\
\hline $\mathrm{NG}$ & - & $38 \mathrm{MJ} \mathrm{m}^{-3}$ & 0.097 & 100 \\
$\mathrm{H}_{2}$ & Chlor-alkali co-product & $120 \mathrm{MJ} \mathrm{kg}^{*}$ & 0.459 & 7.2 \\
$\mathrm{H}_{2}$ & Steam methane reforming & $120 \mathrm{MJ} \mathrm{kg}^{*}$ & 2.85 & 100 \\
\hline
\end{tabular}

*Lower heating value. Combustion product is steam.

In contrast, if the $13.7 \mathrm{kWh} \mathrm{kg}^{-1} \mathrm{H}_{2}$ that are supplied to the electrolysis and liquefaction processes were supplied by the mix of technologies represented in the U.S. grid rather than a specific hydropower plant, overall energy use per $\mathrm{kg}$ of $\mathrm{H}_{2}$ would be expected to show a $216 \%$ increase $\left(174 \mathrm{MJ} \mathrm{kg}^{-1}\right)$. Under this scenario, renewable energy would represent less than $3 \%$ of the total system energy use.

Hydrogen sourced via natural gas reforming is assumed to follow the pattern of a typical steam reforming plant such as the one modelled by Spath and Mann (2001). Spath and Mann considered a 1.5 million $\mathrm{m}^{3}$ per day plant and provided an energy credit for steam generated as a result of the reforming reaction. Total energy associated with production of hydrogen via this method (including the natural gas that serves as the reformer input) is $183 \mathrm{MJ} \mathrm{kg}^{-1}$ of $\mathrm{H}_{2}$ gas produced. An additional $159 \mathrm{MJ} \mathrm{kg}^{-1}$ are required to liquefy and transport the hydrogen.

Natural gas supplied to the microgrid was assumed to follow national average patterns as reported in the U.S. LCI Database Project (NREL, 2005). Accordingly, extraction, processing and delivery of natural gas to the Power Pavilion require $3.7 \mathrm{MJ} \mathrm{m}^{-3}$. The total fuel cycle energy associated with the use of natural gas in the microgrid is $42 \mathrm{MJ}^{-3}$. This includes both upstream processing and combustion of the fuel in a generator. Renewable sources are expected to account for less than $0.03 \%$ of the total energy used in the natural gas fuel cycle. No renewable energy is accounted for in the natural gas system. Energy content and fuel production requirements for both hydrogen and natural gas fuels are shown in Table II.

\subsection{Model development}

This model assumes static or steady-state annual operation of the microgrid. That is, the transient effects of start-up and shut down periods are not considered. For units operated continuously over long periods of time, transient effects are likely negligible. However, in actual operation of generator sets, especially co-generation units, for which start-up and shut-down are more frequent, transient effects may play a greater role than shown here. Static models such as the one used here may overstate the energy and emissions benefits of distributed generation relative to more dynamic models. Voorspools and D'haeseleer (2003) examined the installation of $360 \mathrm{MW}_{\mathrm{e}}$ of centralized cogeneration capacity in both the industrial and commercial sectors in Belgium. They found that the relatively constant heat demand of the industrial sector provided good agreement between static and dynamic models. However, in the economy-wide commercial sector installation examined, static models overstated energy and greenhouse gas emissions benefits by more than 60\% (Voorspools and D'haeseleer, 2003). Voorspools and D'haeseleer have also examined a small-scale cogeneration unit for residential heating. Their analysis determined that the transient effects of heating during start-up lead to a $20 \%$ reduction in heat output during the first hour of operation following a cold-start (Voorspools and 
D'haeseleer, 2002). Static models are used for the NextEnergy installation on the assumption that, on an annual basis, transient periods will be minimal compared to periods of continuous operation.

Using a static model, the electricity $(e)$ and heat $(Q)$ generated by the microgrid system can be determined based on characteristic conversion efficiencies for each generator set (electrical conversion efficiency for generator set $i\left(\mathrm{kWh} \mathrm{MJ}^{-1}\right)=\eta_{e, i}$, thermal conversion efficiency for generator set $i\left(\mathrm{MJ} \mathrm{MJ}^{-1}\right)=\eta_{Q, i}$, solar module conversion efficiency $\left.(\%)=\eta_{\text {solar }}\right)$ combined with fuel energy input to each generator set (natural gas input to generator $i$ at $100 \%$ load $\left(\mathrm{MJ} \mathrm{yr}^{-1}\right)=$ $E_{\mathrm{NG}, i}$, hydrogen input to generator $i$ at $100 \%$ load $\left(\mathrm{MJ} \mathrm{yr}^{-1}\right)=E_{\mathrm{H}_{2}, i}$, solar radiation $\left.\left(\mathrm{kWh} \mathrm{yr}^{-1}\right)=S\right)^{\S}$ and the load factor for each unit $\left(\alpha_{i}\right)$ according to Equations (1) and (2), respectively.

$$
\begin{gathered}
e=\sum \alpha_{i} \eta_{e, i} E_{\mathrm{NG}, i}+\sum \alpha_{i} \eta_{e, i} E_{\mathrm{H}_{2}, i}+\alpha_{\mathrm{solar}} \eta_{\mathrm{solar}} S \\
Q=\sum \alpha_{i} \eta_{Q, i} E_{N G, i}+\sum \alpha_{i} \eta_{Q, i} E_{\mathrm{H}_{2}, i}
\end{gathered}
$$

In a similar fashion, generator set fuel use combined with the upstream energy use data (upstream natural gas fuel cycle energy $\left(\mathrm{MJ} \mathrm{MJ}^{-1}\right)=U_{\mathrm{NG}}$, upstream hydrogen fuel cycle energy $\left(\mathrm{MJ} \mathrm{MJ}^{-1}\right)=U_{\mathrm{H}_{2}}$, solar panel life cycle energy inputs for production divided by expected panel lifetime $\left.\left(\mathrm{MJ} \mathrm{yr}^{-1}\right)=U_{\text {solar }}\right)$ derived from the fuel cycle analysis provides the basis for determining the total primary energy (renewable and non-renewable) used in the operation of the microgrid (E). This relationship is shown in Equation (3). A similar procedure was followed for combining combustion emissions with upstream emissions.

$$
E=\sum \alpha_{i} E_{\mathrm{NG}, i}\left(1+U_{\mathrm{NG}}\right)+\sum \alpha_{i} E_{\mathrm{H}_{2}, i}\left(1+U_{\mathrm{H}_{2}}\right)+U_{\text {solar }}
$$

When only non-renewable fuel inputs are considered, the first and third terms in Equation (3) remain unchanged. ${ }^{\top}$ However, the second term, addressing hydrogen fuels, must be rewritten to remove the combustion of the hydrogen fuel (considered renewable, as described above) and to account for only the non-renewable portion of the upstream production energy $\left(U_{\mathrm{H}_{2}}^{\prime}\right)$. The revised calculation is shown in the following Equation (4):

$$
E^{\prime}=\sum \alpha_{i} E_{\mathrm{NG}, i}\left(1+U_{\mathrm{NG}}\right)+\sum \alpha_{i} E_{\mathrm{H}_{2}, i} U_{\mathrm{H}_{2}}^{\prime}+U_{\text {solar }}
$$

For use in comparing alternative configurations or combination of units within the microgrid, a net energy ratio (NER) value was calculated. Several forms of a NER equation are available (Spitzley and Keoleian, 2004); the values used here are calculated according to Equation (5), which provides an indication of the effectiveness of the system at leveraging non-renewable energy resources for long-term energy supply. Higher values of the NER indicate a more effective use of the existing energy infrastructure.

$$
\mathrm{NER}=\frac{3.6 e+Q}{E^{\prime}}
$$

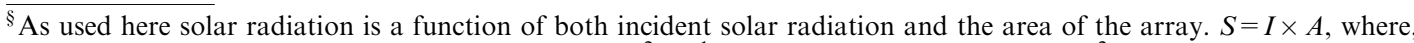
$I=$ average annual incident solar radiation $\left(\mathrm{kWh} \mathrm{m}^{-2} \mathrm{yr}^{-1}\right)$, and $A=$ area of the array $\left(\mathrm{m}^{2}\right)$.

" Recall that the upstream energy use accounted for in the production of the photovoltaic system is derived from nonrenewable fuels.
} 


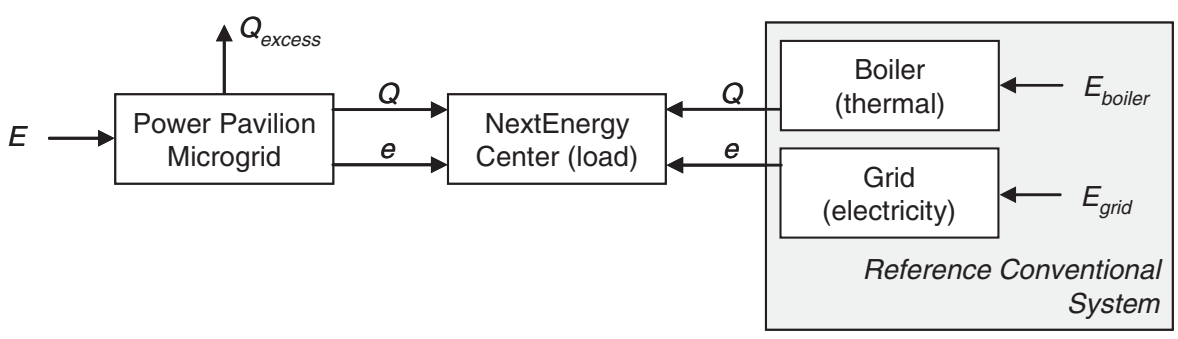

Figure 2. Conventional and microgrid systems for meeting site demand.

The microgrid and conventional systems are shown in Figure 2. For the generator sets studied here, the heat to power ratio $\left(\mathrm{HPR}=Q_{i} / 3.6 e_{i}\right)$ is such that excess heat generation is generally expected at the microgrid. Any heat generated that is not useable for the building load is assumed to be vented to the atmosphere. In calculating the NER under these conditions, the building thermal load is considered the maximum useable heat production and excess heat generation is not included in Equation (5). In this manner, all system configurations are compared at equivalent heat and electrical output to avoid comparisons of systems producing different levels of energy quality. However, control technology installed at the site may help better manage generator operations to more closely match building load and future partnerships may yield sources of demand for excess heat. Under future conditions, system boundaries will need to be carefully defined to avoid comparisons across systems with varying levels of energy quality.

\section{RESULTS}

\subsection{Unit operating data}

Data on the characteristic performance efficiency, fuel consumption, operating conditions, and emissions for each generator set were obtained from supplier interviews and specification sheets. In many cases performance data are based on scale-up of prototype results or limited field testing of equipment (Baron, 2004; Baron et al., 2004). The relevant performance data for the generator sets considered here are shown in Table III. These data are generally consistent with expected operating performance for similar technologies."

The reference case for all systems studied was a combination of the regional electricity fuel mix (local utility) and a conventional industrial thermal system. The regional fuel mix included $76.7 \%$ coal, $18.1 \%$ nuclear, $3.2 \%$ natural gas, $1.4 \%$ hydropower and other renewables, and $0.6 \%$ oil. The conventional thermal system includes a natural gas fired boiler with $75 \%$ efficiency.

For this model, the HPR for each generator set with CHP capabilities was taken at the maximum output level. The real-world operation of this or any microgrid would reflect the need to manage the HPR of individual operating units for seasonal factors. For example, units might be operated to maximize electrical output in the summer months and thermal energy output in winter months. This macro-scale analysis considers the maximum expected performance of each unit in terms of overall energy conversion.

\footnotetext{
${ }^{\|}$See for example Pepermans et al. (2005), Greene and Hammerschlag (2000).
} 
Table III. Generator set performance data.

\begin{tabular}{lccc}
\hline Generator set $(i)$ & $\begin{array}{c}\text { Heat rate }\left(1 / \eta_{e}\right), \\
\mathrm{MJ} \mathrm{kWh}^{-1}\end{array}$ & $\begin{array}{c}\text { Thermal conversion } \\
\text { efficiency }\left(\eta_{Q}\right)\end{array}$ & $\begin{array}{c}\mathrm{CO}_{2} \text { emissions } \\
\left(\mathrm{g} \mathrm{kWh}^{-1}\right)\end{array}$ \\
\hline $\mathrm{H}_{2}$ Fuel Cells & 10.3 & $\mathrm{n} / \mathrm{a}$ & 0.0 \\
NG Stirling Engine & 11.7 & 0.53 & 756 \\
NG Engine-85 & 11.5 & 0.54 & 708 \\
NG Engine-150 & 10.9 & 0.46 & 585 \\
$\mathrm{H}_{2}$ Engine & 11.2 & $\mathrm{n} / \mathrm{a}$ & $0.0^{\dagger}$ \\
Solar Modules & $0.06^{*}$ & $\mathrm{n} / \mathrm{a}$ & $63.5^{\ddagger}$ \\
\hline
\end{tabular}

$\mathrm{n} / \mathrm{a}=$ unit does not have CHP capabilities.

* Solar conversion efficiency $\left(\eta_{\text {solar }}\right)$.

${ }^{\dagger}$ No fuel combustion $\mathrm{CO}_{2}$ emissions are expected, however, non-negligible emissions related to lubricants and fluids are possible.

${ }^{\star}$ Emissions related to module production allocated over a 20 year life in Detroit (Keoleian and Lewis, 2003).

Table IV. Microgrid modelling scenario characteristics.

\begin{tabular}{|c|c|c|}
\hline No. & Objective & Description \\
\hline 1 & $\begin{array}{l}\text { Operate with minimum total } \\
\text { energy input regardless of fuel } \\
\text { source }\end{array}$ & $\begin{array}{l}\text { This scenario establishes the combination of generator sets } \\
\text { and load factors that will most efficiently convert energy } \\
\text { sources into useable heat and electricity }\end{array}$ \\
\hline 2 & $\begin{array}{l}\text { Operate with minimum total } \\
\mathrm{CO}_{2} \text { emissions using hydrogen } \\
\text { sourced from the chlor-alkali } \\
\text { plant }\end{array}$ & $\begin{array}{l}\text { This scenario establishes the minimum total fuel cycle } \mathrm{CO}_{2} \\
\text { emissions levels possible when operating the microgrid. } \\
\text { The use of hydrogen from the chlor-alkali plant provides } \\
\text { the opportunity for the use of a low carbon, renewable fuel }\end{array}$ \\
\hline 3 & $\begin{array}{l}\text { Operate with minimum total } \\
\mathrm{CO}_{2} \text { emissions using hydrogen } \\
\text { sourced from the natural gas } \\
\text { reforming plant }\end{array}$ & $\begin{array}{l}\text { This scenario examines the total fuel cycle } \mathrm{CO}_{2} \text { emissions } \\
\text { implications of using hydrogen from steam methane } \\
\text { reforming. The only renewable fuel available in this scenario is } \\
\text { solar power }\end{array}$ \\
\hline
\end{tabular}

The exception to this is the photovoltaic generator set. Solar modules are available continuously and operate according to the available sunlight. Therefore, when the solar generator set is used it operates at a load factor of $100 \%$ with an average annual capacity factor of $16 \%$ based on estimated generation for continuous operation with solar radiation levels expected in Detroit.

The microgrid fuel cycle model was demonstrated in the investigation of three specific operating scenarios. In each case, a simple, single objective, linear optimization was performed to determine the set of generating unit load factors that best met the stated objective. Although other methods, such as genetic algorithms and simulated annealing, for heuristic optimization of energy supply systems have been demonstrated (González-Monroy and Córdoba, 2002), the linear method employed here is consistent with the static performance data available for the microgrid. Other than the operating limits of the individual units the only constraint on the system was that the microgrid had to supply the complete heat $(Q)$ and electrical $(e)$ demand of the site. The hydrogen fuel source considered also varied between the scenarios. Specific scenario characteristics are provided in Table IV. 


\subsection{Microgrid optimization}

The total fuel cycle model was used to evaluate both the performance of the individual units in the NextEnergy Power Pavilion and their collective ability to efficiently meet site heat and power demand. For individual units, when hydrogen is sourced using renewable energy several generator sets are capable of providing electricity at high NER values. Table $\mathrm{V}$ provides results for individual units run at full capacity with no set heat or electrical load.

Examination of the microgrid for meeting the site demand under the scenario conditions described earlier highlights the benefits of microgrid operation relative to conventional systems and the importance of hydrogen fuel source selection. Results for each simple optimization scenario are shown in Table VI. Scenario 1 demonstrates that reductions in energy use of $38 \%$ relative to a conventional system are possible for microgrid operation. In this case, the microgrid uses no hydrogen fuel, so the choice of a hydrogen source has no influence on the optimization. In Scenario 1, the microgrid produces $8 \%$ more thermal energy than required to meet the site demand. If a use is found for this heat, the total NER for this scenario would increase to 0.72 . Scenario 2 shows that the ideal operation of the microgrid for minimum total $\mathrm{CO}_{2}$ emissions includes the use of all available renewable energy technologies. These renewablefueled generator sets $\left(\mathrm{H}_{2}\right.$ fuel cells, $\mathrm{H}_{2}$ engine and solar modules) do not have CHP capabilities; therefore one of the natural gas generator sets must also be used to achieve necessary thermal output levels. This configuration can provide for the thermal and electrical load of the building while emitting $60 \%$ less $\mathrm{CO}_{2}$ than the reference conventional system. However, these operations result in a higher total energy use than was observed in the first scenario. Nevertheless, with $28 \%$ of energy input from renewable fuels the overall result is a more favourable NER. Scenario 3 indicates the limitations of hydrogen sourced from fossil fuels. In this case, total fuel cycle $\mathrm{CO}_{2}$ emissions are minimized using a single natural gas engine and the solar modules. These results are identical to those observed in Scenario 1.

In order to further investigate the implications of the hydrogen source on the carbon emissions benefits of the microgrid, a scenario was run assuming the hydrogen stored on site at the NextEnergy Power Pavilion included a mix of hydrogen from the two sources (not shown in Table VI). This analysis indicated that only when more than $65 \%$ of the hydrogen came from the chlor-alkali plant did the use of hydrogen in the microgird provide a net $\mathrm{CO}_{2}$ benefit relative to running directly on natural gas. When $65.4 \%$ of the hydrogen is sourced from the chlor-alkali plant, the optimal annual generator set usage includes the solar panels $(100 \%)$, the $150 \mathrm{~kW} \mathrm{NG}$ engine $(46.2 \%)$, and the $\mathrm{H}_{2}$ fuel cells $(36.1 \%)$. These conditions provide total fuel cycle $\mathrm{CO}_{2}$ emissions identical to the all natural gas case (Scenarios 1 and 3) with a slightly lower NER of 0.66. Any increase in the percentage of hydrogen from renewable sources provides further reductions in total $\mathrm{CO}_{2}$ emissions.

Table V. Generator set life cycle performance at full capacity (with $\mathrm{H}_{2}$ from hydropower).

\begin{tabular}{lccc}
\hline Generator set $(i)$ & Electricity generated $\left(e_{i}\right), \mathrm{kWh}$ & Heat generated $\left(Q_{i}\right), \mathrm{MJ}$ & $\mathrm{NER}_{i}$ \\
\hline $\mathrm{H}_{2}$ Fuel Cells & 131000 & - & 10.6 \\
NG Stirling Engine & 964000 & 5970000 & 0.53 \\
NG Engine-85 & 745000 & 4630000 & 0.61 \\
NG Engine-150 & 1310000 & 6560000 & 0.50 \\
$\mathrm{H}_{2}$ Engine & 1050000 & - & 9.74 \\
Solar Modules & 1710 & - & 3.89 \\
\hline
\end{tabular}




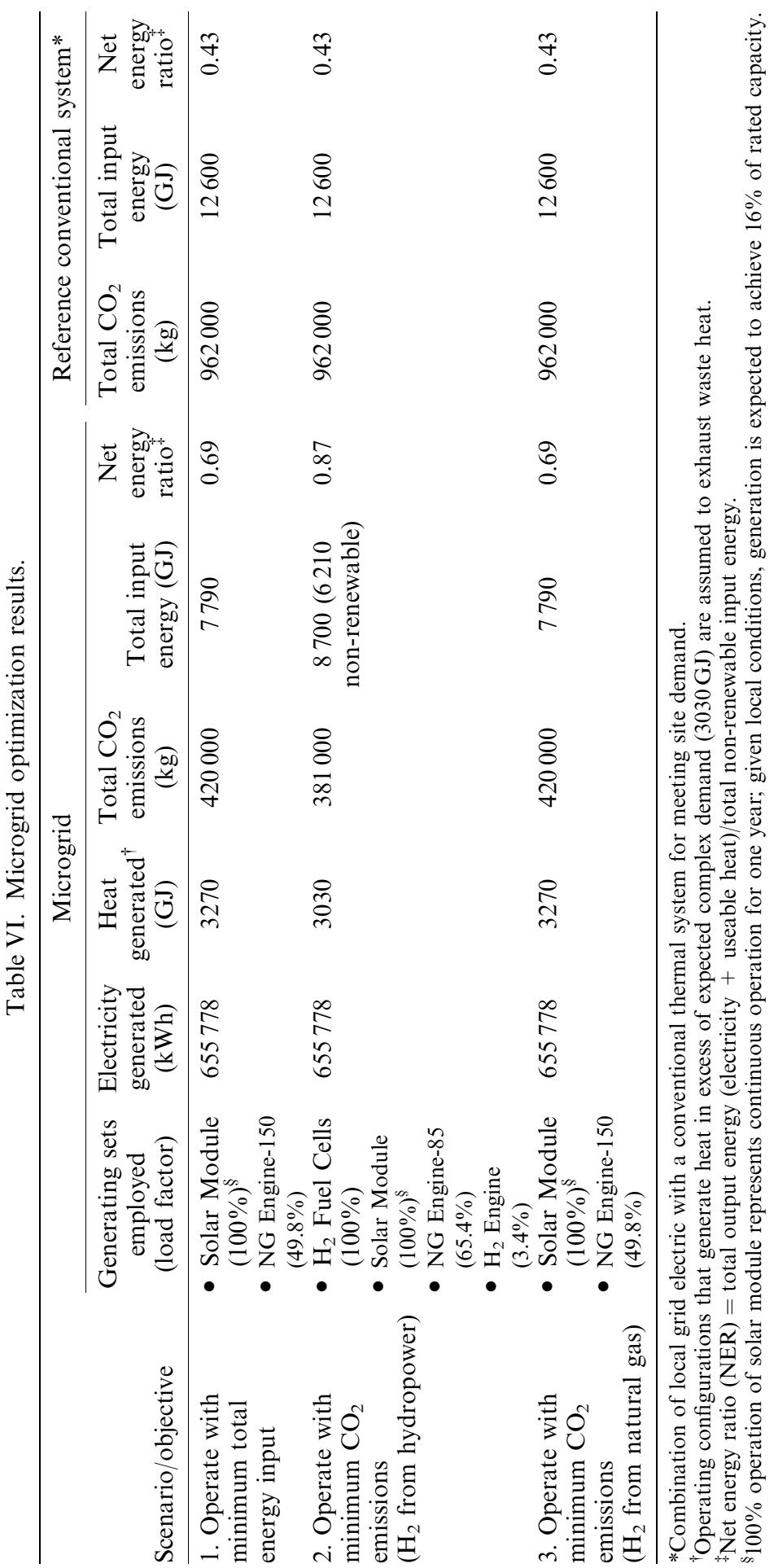


Although not shown here, the objective of maximizing the use of renewable fuels in the microgrid produces results nearly identical to the scenarios for minimizing carbon dioxide emissions. With no available sources of renewable thermal energy, the microgrid will require some fossil fuel use to meet site demand. The operating conditions described in Scenario 2, provide the maximum NER for the NextEnergy Power Pavilion.

\section{DISCUSSION}

Microgrids can offer substantial energy and emissions advantages over conventional centralized power plants with regional grid systems and separate natural gas boilers. Total energy reduction potential of the microgrid studied here could be as high as $38 \%$, while reductions in nonrenewable energy use could reach $51 \%$. These results correspond to improvements of $60-102 \%$ in the system NER relative to conventional alternatives. Similarly, emissions of $\mathrm{CO}_{2}$, a key global warming gas, can be reduced by as much as $60 \%$ relative to conventional heat and power systems.

This modelling activity suggests hydrogen could play a key role in reducing demand for fossil fuels. However, a limited quantity of hydrogen is currently available as a co-product of the chlor-alkali process, and only a small number of these processes are driven by hydropower. Thus only a small quantity of renewable hydrogen fuel is currently available for use in microgrids or other distributed applications. Heavy reliance on fossil-fuel based hydrogen sources, such as steam methane reforming, would currently be required for any substantial expansion of hydrogen-fueled microgrids in the Detroit area. Substituting the more common natural gas hydrogen source for the hydrogen from hydropower results in overall requirements for fossil fuel greater than that required by the direct use of natural gas in combustion engines. Clearly, the identification of viable, large-scale, renewable sources of hydrogen is critical for maximizing the effectiveness of microgrids.

Under all conditions studied, the capability to provide simultaneous heat and power provides substantial advantage for the microgrid system relative to the conventional system. The ability to effectively manage a microgrid to efficiently match both heat and power demand, including seasonal factors and unexpected events, is also key to the success of these systems. Installing technologies appropriately sized to deliver necessary heat and power as efficiently as possible will maximize benefits relative to conventional alternatives.

This modelling activity provides an initial examination of the NextEnergy Power Pavilion. Future studies should examine other distributed generation and microgrid installations using the full fuel cycle perspective. Other analyses of this installation may also provide additional insights. Of particular interest would be the comparison between an economic optimization of microgrid operation and the environmental optimizations shown here. This type of analysis would help indicate where opportunities exist to deliver both financial and environmental benefits relative to conventional alternatives. Finally, future modelling of the NextEnergy microgrid should consider the transient operation of technologies. The estimation of benefits shown here likely overstates the benefits of microgrid operation due to the neglect of transient effects. Operating experience with the installed microgrid, combined with additional testing by suppliers and other users should provide the additional performance data required for development and verification of a more robust model. 


\section{NOMENCLATURE}

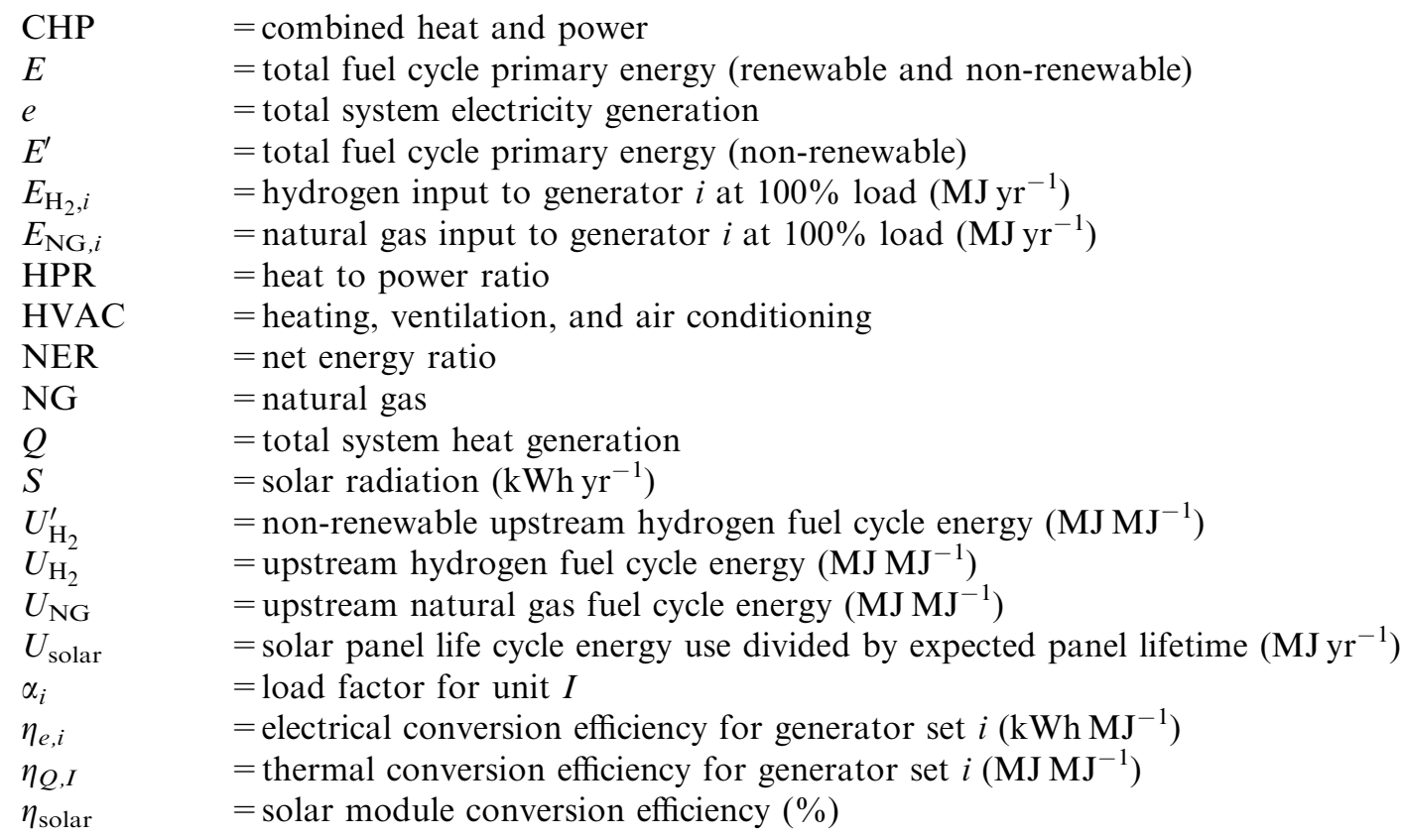

\section{ACKNOWLEDGEMENTS}

The authors would like to acknowledge the contributions of Jim Croce and Dr C. G. Michael Quah from NextEnergy, and Michael Saldana from DTE Energy Technologies, without their technical support and the data they provided this research would not have been possible. A grant from NextEnergy (PSC-03) provided support for the initial microgrid modelling activities and research.

\section{REFERENCES}

Abu-Sharkh S, Arnold, RJ, Kohler J, Li R, Markvart T, Ross JN, Steemers K, Wilson P, Yao R. 2006. Can microgrids make a major contribution to UK energy supply? Renewable and Sustainable Energy Reviews 10(2):78-127. DOI:10.1016/j.rser.2004.09.013.

Baron S. 2004. Motown microgrid; life cycle analysis rates energy and environmental performance. Cogeneration and On-Site Power Production, Earthscan/James \& James: London, November-December, 75-81.

Baron SG, Keoleian GA, Spitzley DV. 2004. Life Cycle Energy and Environmental Analysis of the NextEnergy Microgrid Power Pavilion. Center for Sustainable Systems (CSS04-10): Ann Arbor, Michigan.

El-Khattam W, Salama MMA. 2004. Distributed generation technologies, definitions and benefits. Electric Power Systems Research 71(2):119-128. DOI:10.1016/j.epsr.2004.01.006.

González-Monroy LI, Córdoba A. 2002. Financial costs and environmental impact optimization of the energy supply systems. International Journal of Energy Research 26:27-44. DOI: 10.1002/er.760.

Greene N, Hammerschlag R. 2000. Small and clean is beautiful: exploring the emissions of distributed generation and pollution prevention policies. The Electricity Journal 13(5):50-60. DOI:10.1016/S1040-6190(00)00118-4.

ISO. 1997. 14040 Environmental management-Life cycle assessment-Principles and Framework. International Organization for Standardization: Geneva.

Keoleian GA, Lewis GM. 2003. Modeling the life cycle energy and environmental performance of amorphous silicon BIPV roofing in the US. Renewable Energy 28:271-293. DOI:10.1016/S0960-1481(02)00022-8. 
Keoleian GA, Spitzley DV. 2006. Life cycle based sustainability metrics. In Sustainability Science and Engineering, Abraham MA. (ed.). Elsevier: Amsterdam.

Microgrid at Michigan Power Pavilion. 2003. Photovoltaics Bulletin 12:6.

NREL. 2005. U.S. Life-Cycle Inventory Database. National Renewable Energy Laboratory [cited 14 December, 2005]. Available from http://www.nrel.gov/lci/

Pepermans G, Driesen J, Haeseldonckx D, Belmans R, D'haeseleer W. 2005. Distributed generation: definition, benefits and issues. Energy Policy 33(6):787-798. DOI:10.1016/j.enpol.2003.10.004.

Smith VM, Keoleian GA. 2004. The value of remanufactured engines; life-cycle environmental and economic perspectives. Journal of Industrial Ecology 8(1-2):193-221.

Spath PL, Mann MK. 2001. Life Cycle Assessment of Hydrogen Production via Natural Gas Steam Reforming. National Renewable Energy Laboratory, U.S. Department of Energy, Golden, Colorado.

Spitzley DV, Keoleian GA. 2004. Life Cycle Environmental and Economic Assessment of Willow Biomass Electricity: A Comparison with Other Renewable and Non-Renewable Sources. Center for Sustainable Systems, University of Michigan, Ann Arbor, MI.

Strachan N, Farrell A. 2006. Emissions from distributed vs. centralized generation: the importance of system performance. Energy Policy, in press, Corrected Proof. DOI:10.1016/j.enpol.2005.03.015.

Tester J, Drake E, Driscoll M, Golay M, Peters W. 2005. Sustainable Energy: Choosing Among Options. The MIT Press: Cambridge, MA.

Voorspools KR, D'haeseleer WD. 2002. The evaluation of small cogeneration for residential heating. International Journal of Energy Research 26:1175-1190. DOI: 10.1002/er.843.

Voorspools KR, D'haeseleer WD. 2003. The impact of the implementation of cogeneration in a given energetic context. IEEE Transactions on Energy Conversion 18(1):135-141. DOI: 10.1109/tec.2002.808332. 